\title{
The Glucosamine Content of Human Umbilical Cord Jelly in Normal and Diabetic Pregnancy
}

\author{
R.S. PATRICK and F. WALKER*
}

University Department of Pathology, Royal Infirmary, Glasgow

Received: August 16, 1968

Summary. Umbilical cords have been examined from twenty-one normal full-term pregnancies and from sixteen diabetic pregnancies. Cord thickness measured by planimetry of transverse sections was approximately twice as great in the diabetic compared with the normal material, but did not correspond closely with foetal size. The wet to dry weight ratio of 13.07 for diabetic cords was significantly greater than the figure of $\mathbf{9 . 7 3}$ for normal material. The amount of mucopolysaccharide as assessed by the measurement of glucosamine liberated by hydrolysis of Wharton's jelly was also significantly greater in diabetic cords, measuring $1.32 \mathrm{mg} / \mathrm{g}$ wet woight or $16.41 \mathrm{mg} / \mathrm{g}$ dry weight compared with the normal figures of 1.03 and 9.42 respectively. Diabetic pregnancy is apparently associated with an increased production of mucopolysaccharide, which could account for water retention and increased thickness of the umbilical cord.

Contenu en glucosamine de la gelée du cordon ombilical humain dans la grossesse normale et diabétique

Résumé. On a examiné les cordons ombilicaux do nouveau-nés de 21 mères ayant eu une grossesse normale à terme, et de 16 mères diabétiques. L'épaisseur du cordon, mesurée par planimétrie des coupes transversales, était approximativement 2 fois plus grande chez les diabétiques que chez les femmes normales, mais ne correspondait pas exactement à la taille foetale. Le rapport poids humide/poids sec de 13.07 pour les cordons des diabétiques était significativement plus grand que le rapport de 9.73 pour les cordons des femmes normales. La quantité de mucopolysaccharide, évaluée par la mesure de la glucosamine libérée par hydrolyse de la gelée de Wharton, était également significativement plus grande dans les cordons des diabétiques; elle était de $1.32 \mathrm{mg} / \mathrm{g}$ de poids humide ou de $16.41 \mathrm{mg} / \mathrm{g}$ de poids sec pour respectivement 1.03 et $9.42 \mathrm{chez}$ les femmes normales. La grossesse des diabétiques est apparemment accompagnée d'une production accrue de mucopolysaccharide qui pourrait expliquer la rétention d'eau et l'épaisseur accrue du cordon ombilical.

Der Glucosamingehalt menschlicher Nabelschnur-Sulze bei normalen und diabetischen Schwangerschaften

Zusammenfassung. Die Nabelschnüre von 21 ausgetragenen normalen und 16 diabetischen Schwangerschaften wurden untersucht. An Querschnitten konnte planimetrisch nachgewiesen werden, daß die Nabelschnüre der Neugeborenen diabetischer Mütter doppelt so dick waren wie bei normalen Neugeborenen, wobei sich jedoch kein enger Zusammenhang zur Größe des Foeten herstellen ließ. Das Verhältnis von Feucht- zu Trockengewicht lag mit 13.07 bei den diabetischen Nabelschnüren signifikant höher als bei den normalen mit 9.73. Auch ließ sich als Ausdruck eines erhöhten Mucopolysaccharid-Gehaltes aus der Wharton'schen Sulze diabetischer Nabelschnüre mit $1.32 \mathrm{mg} / \mathrm{g}$ Feuchtgewicht, bzw. $16.41 \mathrm{mg} / \mathrm{g}$ Trockengewicht signifikant mehr Glucosamin freisetzen als aus Normalgewebe (1.03 bzw. $9.42 \mathrm{mg} / \mathrm{g}$ ). Während der diabetischen Schwangerschaft kommt es offensichtlich zu einer verstärkten Bildung von Mucopolysacchariden, die für die Wasserretention und die Zunahme des Durchmessers der Nabelschnüre verantwortlich sein könnte.

Key-words: Diabetic pregnancy, foetal macrosomia, glucosamine, mucopolysaccharide, umbilical cord composition, Wharton's jelly.
The influence of maternal diabetes on the development of the foetus has been the subject of many investigations, and both humoral and genetic factors have been implicated in the causation of foetal macrosomia. It is now generally held that the production of excess insulin by the infant's islet tissue from the stimulus of hyperglycaemia results in the exaggerated synthesis of fat, and this, rather than fluid retention, is responsible for the infant's size (OSLER, 1960; PEDERSen and OsLer, 1961; Steinke and Driscold, 1965). Nevertheless, the umbilical cords of these big babies have a grossly oedematous appearance, and their subsequent shrinkage with loosening of the cord suture has been the cause of serious haemorrhage (Frscher, 1961).

The present study was undertaken to assess the degree of hydration of such umbilical cords together with their mucopolysaccharide content, as any in-

* Present address: Department of Pathology, University of Aberdeen. crease in this connective tissue component would be expected to increase the capacity for water retention. It is problematical whether the anabolic action of hyperinsulinism in the foetus or the diabetic environment provided by the mother can influence the synthesis and composition of homogeneous ground substance. Umbilical cord provides a ready and copious supply of fresh ground substance for such studies, which could be extended to include the influence of pre-diabetes and other endocrine disorders on connective tissue metabolism.

\section{Materials and Methods}

Segments of umbilical cord measuring about $10 \mathrm{~cm}$ in length were obtained as soon as possible after birth from sixteen infants of diabetic mothers and from twenty-one mature infants of normal birth weight (3 to $3.5 \mathrm{~kg}$ ) whose mothers had no diabetic trait and were in good health. These specimens were stored in closed 
containers at $-20^{\circ} \mathrm{C}$. Macrosomia was conspicuous in ten of the sixteen diabetic babies and invariably associated with umbilical cord thickening. Some variation in thickness was evident among the control specimens, but no material from any suspected case of prediabetes or latent diabetes is included.

While still frozen, transverse sections of umbilical cord about $3 \mathrm{~mm}$ thick were made with a sharp scalpel or razor blade. The width of each specimen was assessed from camera lucida drawings of transverse sections taken from at least three levels. By means of planimetry mean transverse area exclusive of vascular area was calculated, and is expressed in square millimetres.

Portions of jelly were dissected free from the outer fibrous covering of the cord and from the blood vessels. The arteries may be pulled away with fine forceps but the vein is sometimes resistant. Any portion showing blood staining was avoided, although this was rarely necessary as blood had been expressed from most cords at the time of collection. The tissue was then minced with fine scissors, and carefully weighed aliquots transferred to glass Soxhlet thimbles for extraction with a hot ethanol-diethyl ether mixture for $24 \mathrm{~h}$. The residue was dried to constant weight in vacuo over phosphorus pentoxide. Other weighed portions of jelly, i.e. unhydrolysed, glucosamine standards were $\mathrm{em}$ ployed in all cases.

In certain selected cases the following supplementary investigations were undertaken: a) the quantitation of hexosamine in both the dried residue and extraction product of cord jelly; b) the use of internal glucosamine standards to assess the possible loss of amino-sugar during hydrolysis and recovery from ionexchange resin columns; c) a comparison of the hexosamine content of blood-stained jelly and unstained jelly from the same specimen.

\section{Results}

\section{Thickness of Cord}

The mean cross sectional area for the diabetic group is increased signicantly above the normal figure of $65.75 \mathrm{sq} / \mathrm{mm}$, although fairly wide variations were encountered in both groups (Table 1 ).

\section{Wet to Dry Weight Ratio}

Approximately 90 per cent of the mass of normal umbilical cord jelly could be extracted with hot aqueous and lipid solvent. A somewhat greater amount

Table 1. Mean values for transverse sectional area, wet to dry weight ratio and glucosamine content of umbilical cords from 21 normal and 16 diabetic pregnancies

\begin{tabular}{|c|c|c|c|}
\hline & $\begin{array}{l}\text { Normal } \\
\text { pregnancies }\end{array}$ & $\begin{array}{l}\text { Diabetic } \\
\text { pregnancies }\end{array}$ & $\begin{array}{l}\text { Comparison of } \\
\text { Means }\end{array}$ \\
\hline & Mean S.E.M. & Mean S.E.M. & $t \quad P$ \\
\hline Area $\mathrm{mm}^{2}$ & $65.42 \pm 4.88$ & $128.99 \pm 19.27$ & $3.159<.01>.001$ \\
\hline $\begin{array}{l}\text { Wet weight/ } \\
\text { dry weight }\end{array}$ & $9.73 \pm 0.57$ & $13.07 \pm \quad 0.69$ & $3.510<.01>.001$ \\
\hline $\begin{array}{l}\text { Glucosamine } \\
\text { mg/g wet weight }\end{array}$ & $1.03 \pm 0.07$ & $1.32 \pm 0.07$ & $2.483<.02>.01$ \\
\hline $\begin{array}{l}\text { Glucosamine } \\
\text { mg/g dry weight }\end{array}$ & $9.42 \pm 0.54$ & $16.41 \pm 0.56$ & $>.001$ \\
\hline
\end{tabular}

Table 2. Correlations between transverse sectional area, wet to dry weight ratio and glucosamine content of umbilical cords from 21 normal and 16 diabetic pregnancies

\begin{tabular}{|c|c|c|c|c|c|c|c|}
\hline \multirow[t]{2}{*}{ Correlation } & \multicolumn{2}{|c|}{ Normal pregnancies } & \multicolumn{2}{|c|}{ Diabetic pregnancies } & \multicolumn{3}{|c|}{ All pregnancies } \\
\hline & $r$ & $P$ & $r$ & $P$ & r & $t$ & $P$ \\
\hline $\begin{array}{l}\text { Wet weight/ } \\
\text { Dry weight } \\
\text { with area } \mathrm{mm}^{2}\end{array}$ & 0.748 & $4.911<.001$ & 0.437 & $1.819<.1>.05$ & 0.581 & 4.224 & $<.001$ \\
\hline $\begin{array}{l}\text { Glucosamine } \mathrm{mg} / \mathrm{g} \\
\text { wet weight with } \\
\text { area } \mathrm{mm}^{2}\end{array}$ & -0.488 & $2.440<.05>.02$ & -0.247 & $0.953<.4>.3$ & -0.028 & 0.163 & $<.9>.8$ \\
\hline $\begin{array}{l}\text { Glucosamine } \mathrm{mg} / \mathrm{g} \\
\text { dry weight with } \\
\text { area }^{2}\end{array}$ & 0.098 & $0.431<.7>.6$ & 0.087 & $0.326<.8>.7$ & 0.423 & 2.764 & $=.01$ \\
\hline
\end{tabular}

0.15 to $0.35 \mathrm{~g}$, were hydrolysed with cation exchange resin (Amberlite $\mathrm{CG} 120-\mathrm{H}^{+}, 100 \mathrm{mesh}$ ) at $105^{\circ} \mathrm{C}$ for $18 \mathrm{~h}$ in sealed glass ampoules fixed on a slowly rotating plate within a hot air oven. Acid eluates of these resins were concentrated to $10 \mathrm{ml}$ and their glucosamine content measured by Boas's (1953) modification of the Elson and Morgan technique. External, could be extracted from the diabetic material and this difference is also statistically significant (Table 1). As might be expected, the ratio can be correlated with cord thickness when calculated for the whole series. This is also true for normal specimens, but there is no close correlation between these values among the diabetic material (Table 2 ). 


\section{Glucosamine recovered by hydrolysis of cord jelly}

Theamount of hexosamine recovered from the hydrolysis of umbilical cord jelly and expressed as glucosamine is approximately $1 \mathrm{mg} / \mathrm{g}$ wet weight. The corresponding figure for the diabetic material in this series was somewhat higher, viz. $1.3 \mathrm{mg} / \mathrm{g}$ wet weight.

When these hexasamine values are related to the dry weight of umbilical cord jelly, the mean difference between the two groups becomes more highly significant (Table 1). Figures relating to the glucosamine of dried, defatted material were obtained for three normal and three diabetic cords, and were approximately similar to those obtained by calculation from the wet/dry weight ratios. This result was expected, since no trace of hexosamine was found in any extraction fluid.

As both cord area and glucosamine content of dried material are increased in diabetic cases, there is some correlation between these two values. No such correlation exists, however, between, these values within the normal and diabetic groups studied separately. A negative correlation between cord thickness and the less significant value for glucosamine calculated on a wet weight basis is found only among the normal cases (Table 2).

The addition of internal standards of glucosamine to material from four normal and two diabetic cases led to a calculated recovery of at least 85 per cent of hexosamine. The presence of blood staining in umbilical cord jelly made no difference to the amount of glucosamine recovered from the single diabetic case in which this feature was investigated.

\section{Discussion}

Human umbilical cord is a rich source of readily available connective tissue mucopolysaccharide, and has been utilized in a number of investigations into the nature of these compounds, e.g., MEYER and PALMren (1936). The major component is hyaluronic acid, but chondroitin sulphates are also present in substantial amounts (JEANLOZ and FoRCHIELLI, 1950; KäRKKÄINEN et al., 1965), together with heparin from mast cells and a sulphated glucosamine compound of uncertain nature (DANISHEFSKY and BELLA, 1966). A trior tetra-saccharide precursor has also been described, but is markedly reduced in the later months of pregnancy when the composition as found at birth becomes established (Schoenbero and Moore, 1958). Hyaluronic acid in particular has a high capacity for water binding, and a water content of approximately 90 per cent of the cord mass has also been recorded by Mischet (1959).

HALIEN (1960) found a total of 1.3 per cent hexasamine in frozen dried umbilical cord, and a similar figure may be calculated from the amount of individual mucopolysaccharides recorded by Danishefsky and Bella. Some of our own normal specimens yielded com. parable amounts, but the overall mean value was 0.94 per cent. Higher direct or calculated figures are given in earlier publications (HADrDIAN and. PIRIE, 1948; JEANLOZ and ForCHIELLI, 1950). We have chosen $18 \mathrm{~b}$ as the optimum safe period of hydrolysis when loss of hexosamine should be negligible (HAAB and ANastasSIADIS, 1961). In our experience of recovery of internal standards added prior to hydrolysis, there can be a reduced yield of up to 15 per cent.

We have assessed the quantity of mucopolysaccharides in terms of glucosamine, whereas galactosamine-yielding compounds also exist within the cord, the glucosamine - galactosamine ratio being 3.5 (H.ALLEN). The exact distribution of these compounds is not known, but there is histochemical evidence to show that much chondroitin sulphate exists in the inner arterial walls (Moore and ScHoENBERG, 1957), which we have excluded from our investigations.

Considerable exchange of water occurs between the foetal circulation and amniotic fluid by passage across the substance of the umbilical cord, (HuTchinson et al., 1959; Plwntu, 1961). However, we found no free or bound hexosamine in the extraction fluid, and blood staining of cord jelly did not influence the result in one case in which this was investigated.

Our glucosamine estimations clearly indicate that diabetic pregnancy is associated with an increase of homogeneous, ground-substance mucopolysaccharides in umbilical cord. These macromolecules normally entrain water (SCHUBERT, 1966), and their excess can help to explain the related increase in cord size. Similar changes have been demonstrated in the vitreous humour of some cases of diabetes mellitus (WALKER and PATricK, 1967), but, in the eye, the sclera effectively prevents an increase in the volume of the vitreous.

We have found that infantile macrosomia is invariably associated with some degree of umbilical cord enlargement, although there is no close correlation between these two observations, and some babies of diabetic mothers had grossly thickened cords, although not conspicuously overweight. A fairly wide variation in cord thickness was also observed among our control group of babies who were all of normal birth weight. Consequently, the cord dimensions may be influenced by factors other than those which influence the size of the rest of the foetus. The total water content of big babies of diabetic mothers is not excessive, and may in fact be less than normal (OsLer and PEDERSON, 1960), with a shift from the extra-cellular to intra. cellular phase during the first few days of life. Nevertheless, local injection of hyaluronidase can reduce subcutaneous swelling, which suggests the presence of excessive water-retaining mucopolysaccharides at this site (DoRFMAN, 1958).

It is claimed that in insulin-deficient states carbohydrates are directed into metabolic pathways which are independent of insulin and in consequence an excess of hexosamine-containing compounds are syn- 
thesised (SPIRo, 1963). This theory can certainly account for the change in alloxan-diabetic vitreous humour (WALKeR and Patrick, 1968), but it does not readily explain the changes in human diabetic vitreous humour or in human umbilical cord jelly. In diabetic pregnancy there is an increase in the amount of umbilical cord insulin associated with hyperplasia of the foetal islet tissue (BAIRD and FARQUHAR, 1962; STIMMr.ER et al., 1964; SHTMA et al., 1966). This endogenous insulin could be inhibited by maternal insulin antibody, which unlike the hormone itself, can cross the placental barrier (SPELLACY and GOETZ, 1963; JøRGENSEN et al., 1966). There is, however, no relationship between the degree of infantile islet hyperplasia and the presence or absence of insulin antibody in the circulation of these infants (STEINKe and Driscoll, 1965).

Alternatively, the increase in amount of cord jelly may be regarded as a manifestation of a general anabolic process. Evidence for excessive growth hormone or placental lactogenic hormone activity in the causation of foetal macrosomia in diabetes is unconvincing (BECK et al., 1965; JoAssin et al., 1967; Laron et al., 1967). Insulin itself has anabolic activity, stimulating the synthesis of protein in experimental animals (SALTER and BEST, 1953) and in the neonate (NAEYE, 1965); moreover, neonates may increase in size following the administration of exogenous insulin for temporary hyperglycaemia (Hutchison et al., 1962). It is quite likely that high level endogenous insulin in these babies may stimulate the synthesis, not only of protein, but also of protein-polysaccharide complexes.

While it seems possible that the cause of excess basement membrane and vitreous polysaccharide in the established adult diabetic may be different from the cause of excess Wharton's jelly, it would, nevertheless, be of interest to determine whether the alteration in the composition of the umbilical cord which we have described can accompany the foetal enlargement of prediabetic pregnancy. The detection of such changes in mucosubstance in early diabetes and possibly in the pre-diabetic state is clearly relevant to an understanding of their pathogenesis.

Acknowledgements. The authors wish to thank Dr. M.J. Patrick, Department of Paediatrics, Stobhill General Hospital, Glasgow and Dr. J.W. FARQUHAR, Department of Child Health, University of Edinburgh, for supplying material for this investigation.

\section{References}

BAIRD, J.D., and J.W. FARQUHAR: Insulin-secreting capacity in newborn infants of normal and diabetic women. Lancet 1962 I, $71-74$.

Beck, P., M.L. Parker, and W.H. Daughaday: Radioimmunologic measurement of human placental lactogen in plasma by a double antibody method during normal and diabetic pregnancies. J. clin. Endocr. 25, 14571462 (1965).

BoAs, N.F.: Method for the determination of hexosamine in tissues. J. biol. Chem. 204, 553-563 (1953).
Danishefsky, I., and A. Bella, Jr.: The sulfated mucopolysaccharides from human umbilical cord. J. biol. Chem. 241, 143-146 (1966).

DORFMAN, A.: Studies on the biochemistry of connective tissue. Pediatrics (Springfield) 22, 576-579 (1958).

Fischer, A.E.: Management of the newborn infant of the diabetic mother. N.Y.St. J. Med. 61, 292-296 (1961).

HaAb, W., and P.A. Anastasstadis: A study on the liberation of sugars, hexuronic acid, and hexosamine from biological material. Canad. J. Biochem. 39, 671681 (1961).

Hadidian, Z., and N.W. PrRre: The preparation and some properties of hyaluronic acid from human umbilical cord. Biochem. J. 42, 260-265 (1948).

HaLLÉN, A.: Extraction of mucopolysaccharides from connective tissue. Acta chem. scand. 14, 1828-1832 (1960).

Hutchinson, D.L., M.J. Gray, A.A. Plente, H. AlVAREZ, R. Caldfyro-Barcta, B. KaptaN, and J. LiNo: The role of the foetus in the water exchange of the amniotic fluid of normal and hydramniotic patients. J. clin. Invest. 38, 971-980 (1959).

Hutchison, J.H., A.J. KeAY, and M.M. KerR: Congenital temporary diabetes mellitus. Brit. med. J. 1962 II, $436-440$.

JeAnLOz, R.W., and E. Forchielli: Studies on hyaluronic acid and related substances. I. Preparation of hyaluronic acid and derivatives from human umbilical cord. J. biol. Chem. 186, 495-511 (1950).

Joassin, G., M.L. Parker, R.S. Puble, and M. CornBLATH : Infants of diabetic mothers. Diabetes 16, 306311 (1967).

Jørgensen, K.R., T. Dechert, L.M. Pedersen, and J. Pedersen : Insulin, insulin antibody and glucose in plasma of newborn infants of diabetic women. Acta endocr. 52, 154-167 (1966).

KäRKKÄINEN, J., A. Lehtonen, and T. NIKkaRI: Determination of glucosamine and galactosamine by gas chromatography. J. Chromat. 20, 457-462 (1965).

Laron, Z., S. Mannhemmer, M. Nimzan, and J. GoldMANN: Growth hormone, glucose, and free fatty acid levels in mother and infant in normal, diabetic, and toxaemic pregnancies. Arch. Dis. Childh. 42, 24-28 (1967).

MeYer, K., and J.W. Paminer: On glycoproteins: II. The polysaccharides of vitreous humor and of umbilical cord. J. biol. Chem. 114, 689-703 (1936).

Mischer, W.: Der Wasser- und Mineralgehalt der normalen, reifen menschlichen Nabelschnur. Arch. Gynäk. 191, 85-95 (1959).

Moore, R.D., and M.D. SoHownBerg: Studies on connective tissue. I. The polysaccharides of human umbilical cord. Arch. Path. 64, 39-45 (1957).

NAEYE, R.L.: Infants of diabetic mothers : a quantitative, morphologic study. Pediatrics (Springfield) 35, 980$988(1965)$.

OsLER, M.: Body water of newborn infants of diabetic mothers. Acta endocr. 34, 261-276 (1960):

-, and J. PeDErsen: The body composition of newborn infants of diabetic mothers. Pediatrics, 'Springfield' 26, 985-992 (1960).

Pedersen, J., and M. Oscer: Hyperglycaemia as the cause of characteristic features of the foetus and newborn of diabetic mothers. Dan. med. Bull. 8, 78-83 (1961).

Plenst, A.A.: Transfer of water across the perfused umbilical cord. Proc. Soc. exp. Biol. 107, 622-626 (1961).

SALTER, J., and C.H. Best : Insulin as a growth hormone. Brit. med. J. 1953 I, 353 - 356.

SchoknBERG, M.D., and R.D. Moore: Studies on connective tissue. III Enzymatic studies on the formation 
and nature of the carbohydrate intermediate of the connective tissue polysaccharide in the human um. bilical cord. Arch. Path. 65, 115-114 (1958).

Schubert, M. : Structure of connective tissues, a chemical point of view. Fed. Proc. 25, 1047-1052 (1966).

Shrma, K., S. PrIce, and P.P. Foá: Serum insulin concentration and birth weight in human infants. Proc. Soc. exp. Biol. 121, 55-59 (1966).

SPELlacy, W.N., and F.L. Goetz: Insulin antibodies in pregnancy. Lancet 1963 II, 222-224.

SPIRo, R.G.: Glycoproteins and diabetes. Diabetes 12, $223-230$ (1963).

Steinke, J., and S.G. DrIscoll: The extractable insulin content of pancreas from foetuses and infants of diabetic and control mothers. Diabetes 14, 573-578 (1965).
Srimmler, L., J.V. Brazie, and D. O'Brien: Plasmainsulin levels in the newborn infants of normal and diabetic mothers. Lancet 1964 I, 137-138.

Watker, F., and R.S. Patrick: Constituent monosaccharides and hexosamine concentration of diabetic human vitreous humoar. Exp. Eye. Res. 6, 327-331 (1967).

-, and R. S. PATRICK: Effect of insulin on the hexosamine content of alloxan diabetic rabbit vitreous humour. Diabetes 17, 105-107 (1968).

Dr. R.S. PATRTCK

University of Glasgow

Dept. of Pathology

Royal Infirmary

Glasgow, C. 4., Scotland 